УДК 376.091.2

\title{
THE MAIN FACTORS OF INCLUSIVE EDUCATION DEVELOPMENT IN UKRAINE
}

\author{
Malyshevska Iryna, Doctor of Pedagogical Sciences, Professor of the Department of Special \\ and Inclusive Education, Pavlo Tychyna Uman State Pedagogical University. \\ ORCID: 0000-0003-0889-2552 \\ E-mail: irinamalysh66@gmail.com
}

The article outlines the main factors influencing the formation and development of inclusive education in Ukraine. The study analyzes the foreign and domestic experience of modern inclusive trends in education. The research reveals that systematic institutional changes are needed for the development of an inclusive environment in domestic education. This is, first of all, educators' professional thinking and public consciousness. The paper describes the main system-forming factors influencing the formation and development of inclusive educational processes in Ukraine. They are the following: axiological, conceptual and terminological, legislative, regulatory, financial and economic, personnel, scientific and methodological, educational and methodological, material and technical, organizational and social ones.

Keywords: inclusion, inclusive education, system-forming factors of inclusive education, children with special educational needs, inclusive trends, inclusive society, integration, humane society.

\section{ОСНОВНІ ЧИННИКИ РОЗВИТКУ ІНКЛЮЗИВНОЇ ОСВІТИ В УКРАЇНІ}

Малишевська Ірина, доктор педагогічних наук, професор кафедри спеціальної та інклюзивної освіти, Уманський державний педагогічний університет імені Павла Тичини. ORCID: 0000-0003-0889-2552

E-mail: irinamalysh66@gmail.com

У статті сформульовано основні чинники впливу на становлення та розвиток інклюзивної освіти в Україні. Проаналізовано закордонний та вітчизняний досвід сучасних інклюзивних тенденцій в освіті. Досліджено, щзо для розвитку інклюзивної практики вітчизняної освіти потрібні системні інституиійні зміни. Доведено, щзо до найскладніших змін відносять професійне мислення педагогічних фахівців та свідомість усього суспільства, щзо впливає на економічні та фінансові основи функиіонування усієї системи освітньої інклюзії. Визначено, щуо на иляху впровадження інклюзивної освіти виникає багато соціальних проблем, зокрема: стереотипи $і$ забобони; відмова педагогічних прачівників, дітей та їхніх батьків прийняти нові принциии освіти; нестача комплексних психолого-педагогічних знань і технологій, спеціальних моніторингових досліджень досвіду вітчизняної інклюзивної освіти. Зафіксовано, що супротивники інклюзї наводять основні чинники, які, на їхню думку, обтрунтовують недочільність інклюзивної освіти: суспільство неготове до такої форми освіти; психологопедагогічні фахівці неготові до реалізачії інклюзії. Визначено завдання пошуку шляхів розуміння основної ідеї інклюзії, яка забезпечує рівне ставлення до всього дитячого розмаїття. Розв'язання цього першочергового завдання забезпечить свідому підготовку педагогічних фахівців на всіх рівнях освіти: від системи навчання здобувачів вищяої освіти до системи підвищення кваліфікації педагогічних працівників закладів освіти.

Окреслено основні системотвірні чинники впливу на становлення та розвиток інклюзивних 
освітніх проиесів в Украӥні. До них віднесено: изінісний, понятійно-термінологічний, законодавчий, нормативно-правовий, фінансово-економічний, кадровий, науково-методичний, навчально-методичний, матеріально-технічний, організачійний, громадський.

Для визначення закономірностей розвитку інклюзивної освіти необхідним є вивчення ї̈ основних сочіально-філософських кониептів.

Ключові слова: інклюзія, інклюзивна освіта, системотвірні чинники інклюзивної освіти, діти з особливими освітніми потребами, інклюзивні тенденції, інклюзивне суспільство, інтеграція, гуманістичне суспільство.

The current stage of educational inclusion development in Ukraine is fraught with controversy and problems. It requires open professional dialogue, a constructive search and study of foreign and domestic experience and common ground. Educational institutions' readiness for change is important for this process. The development of inclusive education practices needs systemic institutional changes but it takes a long time. Meanwhile, the most difficult changes are changes in professional thinking and public consciousness starting from the educator's psychology and ending with economic and financial foundations of the whole system performance. Inclusive education provision encounters not so much barrier-free environment organization problems as social problems. Inclusion opponents outline the main factors that, in their opinion, substantiate inclusive education inexpediency arguing that society and teachers are not ready for this form of education. It is obvious that proponents of the outdated bureaucratic system, including the education system, under the guise of democratic slogans and the need to develop a new information society are trying to find justification for their reluctance to find a place for people with special educational needs in this society. It is not necessary to look for ways to "cleanse" the state for such people; what needs to be done is finding ways to get the basic idea of inclusion - we are all different and the whole world is for us, and not vice versa. Addressing this priority will reduce the problem of "unpreparedness" for inclusion at all education levels to nothing.

Therefore, domestic education requires major changes to overcome the above problems. This is not only streamlining the education system under the law and the implementation of government programs related to accessible educational environment provision but also changing the worldview of the heads of educational institutions and educators' professional thinking.

Some domestic and foreign researchers address the problem of improving inclusive education development (L. Budiak, T. Dehtiarenko, V. Zasenko, A. Kolupaeva, I. Kuzava, Z. Leniv, S. Lytovchenko, J. Lupart, T. Loreman, N. Nazarova, E. Nida, T. Sak, M. Semaho, N. Semaho, N. Sofii, O. Taranchenko, V. Tarasun, O. Fedorenko). The analysis of their scientific research shows that because of world globalization, democratization and humanization processes, the influence of foreign educational space, an inclusive education model is being formed in the modern Ukrainian educational system aimed at the creation of a new civilized and humane society.

The article sets out to identify the main factors influencing the formation and development of inclusive education in Ukraine.

The introduction of inclusive education in Ukraine is a complex and intricate problem that requires consideration and development of regulatory, psychological and pedagogical, program and content as well as social and psychological principles.

Examining the conditions of inclusion in general secondary education, Canadian 
scientist T. Loreman formulated the "seven pillars of support" for inclusive education. Each of the seven pillars of support represents a prerequisite for successful inclusion [2].

Pillar one: development of a positive attitude. The development of a positive attitude in educators is the main prerequisite for inclusive education. Nourishing a positive attitude towards inclusive education should be carried out at all levels starting from the system of teaching pedagogy students and ending with experienced practitioners.

Pillar two: policy and leadership aimed at providing support. A key element in creating inclusive schools is the support of school leaders.

Pillar three: school and classroom processes grounded in research-based practice. To make inclusion truly successful, the entire school should change and adapt to meet all students' diverse needs. Teachers need to contemplate their new role - a transition from being "science teachers" to becoming "teachers of children". It is important to organize children into heterogeneous groups of different ages and with different abilities. Teachers need to work in heterogeneous teams with teacher assistants and other support staff.

Pillar four: flexible curriculum and pedagogy. More child-centered learning techniques are useful for inclusion. Inclusion and the overall quality of education will improve if teachers reflect on their philosophical views and adapt their teaching techniques to best practices.

Pillar five: community involvement. The most important group in the wider school community is parents. Partnerships with other local, national and international community organizations can also be helpful.

Pillar six: meaningful reflection. Reflection is becoming an increasingly important part of teachers' continuous professional development techniques. The value of reflection increases if it is based on data that have been collected because of systematic observations of teachers' practical work. (This statement emphasizes the leading role of the teacher-researcher in inclusive education organization).

Pillar seven: necessary training and resources. One useful model is to form a university-school partnership. Other resources considered useful for schools and teachers include extra time for planning, as well as additional staff to act as assistants.

Thus, for inclusive education success in the country's educational space it is necessary to form and facilitate the functioning of a well-organized and well-established infrastructure of specialized pedagogical, psychological and social assistance to children with special educational needs who study at preschool and general secondary education institutions.

In Ukraine, for several decades, inclusive innovations have been implemented mainly by extrapolation, i.e. by experimental transfer and adaptation of the modifications of certain foreign approaches to domestic conditions. Such activities are initiated and carried out mainly by special education system representatives, sometimes with reliance on foreign charities. At the same time, mass education remains unchanged. The introduction of inclusion in the mass school education system cannot be painless or traceless for the system itself.

At present, the term "children with special needs" is used in different countries' international legal documents. The term "special needs" is used concerning individuals, whose social, physical, or emotional characteristics require special attention and services contributing to their potential development [1, p. 256]. In 1994, the Salamanca Statement internationally declared the term "children with special educational needs" [5].

Inclusive education in Ukraine has its historical and cultural roots, so it is expedient to create a national inclusive education model. In addition to the humanistic paradigm (taking 
into account the diversity of children's groups and each child's features and needs), new terminological concepts should be taken into account, because the content of new concepts reveals the essence of the inclusive education phenomenon. Therefore, inclusive education system-forming factors include conceptual and terminological vocabulary. The logical solution to this problem requires clear definitions, which, first of all, would characterize the child as a subject of development and an object of psychological and pedagogical influence in an inclusive educational environment.

Within the legal framework and in the social protection sphere in Ukraine new terminology is currently used, in particular "children with special educational needs", which gradually becomes common and understandable. A. Kolupaeva includes all children whose educational needs go beyond the conventional norms with children with special educational needs. These are children with mental and physical disabilities, including disabled children, gifted children and vulnerable children (e.g., orphaned children, etc.) [4, p. 305]. Individuals who for various reasons are in need of extra support and the use of adaptive pedagogical techniques are referred to as those who have special needs. The causes can be (but not limited to) physical and mental disabilities. Educational programs for children with special educational needs are developed taking into account the individual needs of students whose training requires additional resources (for example, specially trained staff, equipment or space) [3]. This approach to the studied term interpretation is especially noteworthy because within the framework of clear educational content it outlines the necessary components without which it is impossible to create an inclusive educational environment: staffing, methodological support and educational institutions that can provide students with additional special services.

Thus, the term "children with special educational needs" has a clear pedagogical component. This term is used both in legislation and in the field of inclusive education.

The analysis of foreign and domestic experience and modern educational trends allows us to identify the main factors influencing educational inclusion formation and development in Ukraine.

The axiological factor is aimed at forming a system of humanistic and democratic value orientations as a determinant of the spiritual development of a society based on inclusion provisions. It provides the formation of a positive attitude to inclusive education philosophy, every person with special educational needs at the level of the state, society, educational institutions and every citizen.

The conceptual and terminological factor performs an interdisciplinary function. It directly affects the formation of principles, standards, laws, patterns and innovations of inclusion within a single terminological field as well as the conceptual culture of society; it allows the clarification of the inclusive education object, purpose, objectives, and trends clearly defining the status of people with special educational needs.

The legislative factor is the only legislative tool ensuring the rights of individuals with special educational needs. The main function of this factor is to improve national legislation, to regulate it following the international conventions, to exercise the rights of people with special educational needs and to regulate the country's obligations towards this group of people.

The regulatory factor forms a system of legal remedies and phenomena (rules, norms, standards, etc., the practice of state and public control over their enforcement) aimed at 
regulating public relations and inclusive tendencies in a country. Improving inclusive education legal framework should be aimed at increasing the number of regulations with the highest legal force, the formation and legal enshrining of basic legal norms related to the most important educational inclusion issues as well as the development of effective mechanisms for their implementation and control.

The financial and economic factor affects inclusive education physical and social infrastructure: the development of material and human resources, stimulating scientific and technological progress and the improvement of the institution of inclusive education provision. In addition, this factor provides adequate labour remuneration, a system of benefits and compensations, moral and material incentives for all inclusive education subjects.

The personnel factor is aimed at providing the inclusive education sphere with highly qualified personnel. It primarily performs a multi-agency function ensuring professional cooperation among interdisciplinary professionals and providing medical, scientific and methodological, social, psychological, educational and methodological as well as correctional support for children with special educational needs. In addition, the personnel factor stimulates an increase in wage-rates for inclusive education institutions' psychological and pedagogical staff and their professional education. To train inclusive education staff, it is necessary to expand the system of professional training based on higher education institutions, advanced training institutes, correctional, rehabilitation centers, and special centers for methodological support for teachers working in the conditions of inclusion.

The scientific and methodological factor is aimed at forming specific inclusive education theoretical and methodological tools (the development of techniques and pedagogical technologies for learning and training in a heterogeneous educational environment; the development of technologies of psychological and pedagogical support of children with special educational needs at all inclusive education levels, etc.) reflecting the dynamics of global inclusive processes and taking into account a positive experience of their implementation in educational practice. All scientific research and innovations should be practice-oriented, take into account the peculiarities and state of domestic education and be aimed at forming a single effective inclusive educational space in the country.

The educational and methodological factor involves the creation of scientificmethodological and didactic support (curriculum) for the development of inclusive processes in preschool and general secondary education based on differential and multi-level approaches.

The material and technical factor is connected with the technology level and advancements, the introduction of inclusive innovations in education and the improvement of inclusive education tools and organization forms. This factor ensures that children with special educational needs have equal access to educational services by adapting educational institutions' room architecture, distance learning introduction, the provision of transport, the creation of a system of inclusive resource centers and facilities as well as the facilitation of inclusive education with special equipment and tools.

The organizational factor ensures the formation of an information connection system, management decisions, organizational and administrative arrangements that affect the formation of a clear educational process structure in terms of inclusion consisting of: inclusively motivated leadership system at various levels (from line ministries to the heads of educational institutions); interaction of pedagogical and support staff based on mutual 
understanding, tolerance and mutual aid; organization of an inclusive educational environment and technology of work in such environment; educational activity organization of children with special educational needs (formation of heterogeneous groups and flexible universal schedule; organization of individual work and targeted consultations, etc.).

The social factor performs regulatory and control functions. Public organizations and parents' associations influence the development of inclusive processes in education monitoring the country's fulfillment of its obligations to respect the rights of children with special educational needs to education. Parents who are customers of inclusive services in education, together with public organizations can act as controllers of service quality, as well as patrons and sponsors of individual inclusive education institutions.

Based on the above inclusive education development factors, let us characterize the features of the future of an inclusive society:

- availability and enforcement of relevant legislation in the country based on which inclusive education provision will be possible;

- economic security of these legislative acts;

- absence of regulatory and bureaucratic complexity of inclusive education innovations;

- education and training of individuals with special educational needs are considered as a separate and independent task of mass and special education professionals;

- professionals' readiness and ability to work at an inclusive educational institution;

- introduction of a system of measures for the prevention, early recognition and early comprehensive support of children with special educational needs and their families;

- conducting systemic educational process restructuring by preschool and general secondary education institutions; it will make it possible to enroll children with special educational needs and allow their full participation in education and the whole life of an institution;

- differentiation of children's educational needs as a basis for their education organization, which involves a careful and individual educational environment selection to prevent secondary disabilities in a child's development;

- inclusive educational environment certification in general education institutions;

- openness of the inclusive education system;

- availability of social and psychological-pedagogical conditions for the life of a child with special educational needs in the family and the full participation of the family in its upbringing;

- observance of parents' right to choose an educational institution for their child with special educational needs and economic support for the execution of this right;

- social security of inclusive education (transport, living conditions and social relations, architecture and proximity of an educational institution, etc.);

- adherence to the voluntariness principle: all participants in inclusive education interact and cooperate voluntarily.

Before anything else, an inclusive society should require domestic education to avoid social segregation of children with special educational needs and provide them with the 
opportunity to participate in preschool and general secondary education institutions' group life. These factors outline a wide range of different inclusive education development aspects in Ukraine. The viability and effectiveness of such a system depend not only on the arrangement level of each inclusion realization condition but also on the systematic and simultaneous implementation of all the above factors.

In the process of determining the patterns and barriers to educational inclusion development, its main socio-philosophical concepts should be considered from a holistic perspective.

\section{СПИСОК ВИКОРИСТАНИХ ДЖЕРЕЛ}

1. Ги Лефрансуа. Психология для учителя. Прикладная педагогическая психология. Санкт-Петербург: Прайм-Еврознак; Москва: Олма-Пресс, 2005. 416 с.

2. Лореман Т. Сім стовпів підтримки інклюзивної освіти. Дефектологія. Особлива дитина: навчання та виховання. 2010.№ 3. С. 3-11. URL: http://www.education-inclusive.com/wp-content/docs/2013/02/ lorman_sim_stovpiv_inclusion-3.2010.pdf

3. Международная стандартная классификация образования МСКО 2011 / Институт Статистики ЮHЕСКО. URL: http://uis.unesco.org/sites/default/files/documents/isced-2011-ru.pdf.

4. Основи інклюзивної освіти: навч.-метод. посіб. / за заг. ред. А. А. Колупаєвої. Київ: А. С. К., 2012. 308 c.

5. Саламанская декларация и рамки действий по образованию лиц с особыми потребностями. URL: http://www.un.org/ru/documents/decl_conv/declarations/ pdf/salamanka.pdf

\section{REFERENSES}

1. Gi Lefransua. (2005). Psihologija dlja uchitelja. Prikladnaja pedagogicheskaja psihologija [Psychology for the teacher. Applied educational psychology]. Sankt-Peterburg: Prajm-Evroznak; Moskva: Olma-Press [in Russian].

2. Loreman, T. (2010). Sim stovpiv pidtrymky inkliuzyvnoi osvity [Seven pillars of support for inclusive education]. Defektolohiia. Osoblyva dytyna: navchannia ta vykhovannia, 3, 3-11. URL: http://www. education-inclusive.com/wp-content/docs/2013/02/lorman_sim_stovpiv_inclusion-3.2010.pdf [in Ukrainian].

3. Mezhdunarodnaja standartnaja klassifikacija obrazovanija MSKO 2011 [International Standard Classification of Education ISCED 2011]. Institut Statistiki JuNESKO. (2011). URL: http://uis. unesco.org/sites/default/ files/documents/isced-2011-ru.pdf [in Russian].

4. Osnovy inkliuzyvnoi osvity [Inclusive education fundamentals]. A. A. Kolupaieva [Ed.]. (2012). Kyiv: A.S.K. [in Ukrainian].

5. Salamanskaja deklaracija i ramki dejstvij po obrazovaniju lic s osobymi potrebnostjami [The Salamanca Statement and Framework for Action on Special Needs Education]. URL: http://www.un.org/ru/documents/ decl_conv/declarations/pdf/salamanka.pdf [in Russian]. 